\title{
Effect of oestradiol-17 $\beta$ on ovarian and serum concentrations of relaxin during the second half of pregnancy in the rat
}

\author{
M. S. Lao Guico and O. D. Sherwood \\ University of Illinois College of Medicine at Urbana-Champaign and Department of Physiology and \\ Biophysics, University of Illinois, Urbana, Illinois 61801, U.S.A.
}

\begin{abstract}
Summary. Immunoactivity concentrations of ovarian relaxin, serum relaxin and serum progesterone were determined from Day 12 through Day 18 of pregnancy in rats treated with oil or oestradiol-17 $\beta$ after hysterectomy or hypophysectomy and hysterectomy on Day 12. Relaxin and progesterone concentrations increased between Days 12 and 18 in sham-operated rats but failed to increase or declined in oil-treated hysterectomized or hypophysectomized-hysterectomized animals. Oestradiol treatment increased serum concentrations of relaxin and progesterone in hypophysectomized-hysterectomized rats on Day 15 and increased the concentrations of ovarian and serum relaxin and serum progesterone in hysterectomized rats on Day 18. These data are consistent with the concept that placental support for the promotion and maintenance of relaxin and progesterone concentrations from Day 12 through Day 18 may be mediated, at least in part, through a common mechanism(s) which involves oestradiol.
\end{abstract}

\section{Introduction}

The corpora lutea (CL) are the source of the polypeptide hormone relaxin in the pregnant rat (Anderson \& Long, 1978; Hudson, Haley, Cronk, Shine \& Niall, 1981; Golos, Weyhenmeyer \& Sherwood, 1984). Relaxin concentrations increase in the ovaries and serum from around Day 10 of pregnancy until Day 20 and decline rapidly 1 or 2 days before birth (Anderson, Bast \& Melampy, 1973; Sherwood, Crnekovic, Gordon \& Rutherford, 1980).

The placenta is required for the promotion and maintenance of high concentrations of relaxin in the serum and ovaries (Goldsmith et al., 1981; Golos \& Sherwood, 1982), as it is for CL growth and progesterone secretion (Takayama \& Greenwald, 1973; Gibori, Antczak \& Rothchild, 1977; Kato, Morishige \& Rothchild, 1979; Golos \& Sherwood, 1982). Placental support for CL growth, progesterone secretion, relaxin synthesis and relaxin secretion may be mediated, at least in part, through a common mechanism from Day 12 to Day 18 (Golos \& Sherwood, 1982); oestradiol formed by intraovarian aromatization of androgens (Gibori \& Keyes, 1978) may be a component in this mechanism. In the absence of the placenta and the maternal pituitary after Day 12, daily s.c. injections of $100 \mu \mathrm{g}$, but not of 25 or $50 \mu \mathrm{g}$, oestradiol-17ß increased CL weight on Day 20 and serum progesterone concentrations to values similar to those in intact animals until Day 16 (Gibori et al., 1977). The authors argued that the high systemic level of oestradiol was necessary to achieve a high intraluteal oestrogen concentration required for luteal function in hypophysectomized-hysterectomized rats. Indeed, it was demonstrated that daily injections of $100 \mu \mathrm{g}$ oestradiol-17 $\beta$ in hypophysectomized-hysterectomized rats increased intraluteal oestradiol concentrations to values above that in sham-operated animals (Gibori \& Keyes, 1978). Daily injections of $100 \mu \mathrm{g}$ oestradiol$17 \beta$ also attenuated the drop in serum concentrations of relaxin which occurred after hysterectomy on Day 15 (Goldsmith, de la Cruz, Weiss \& Castracane, 1982). However , the effect of oestradiol 
treatment in ovarian and serum concentrations of relaxin after combined hypophysectomy and hysterectomy on Day 12 has not been reported.

The present study was conducted to examine further the possibility that the concentrations of ovarian and serum relaxin and serum progesterone from Day 12 to Day 18 may be regulated by a common mechanism(s) which involves oestradiol.

\section{Materials and Methods}

Animals. Primiparous Sprague-Dawley-derived rats, mated at about 90 days of age, were obtained from Holtzman Co. (Madison, WI). The day on which spermatozoa were found in the vagina was designated Day 1 . Animals were caged individually in a room maintained at $23-25^{\circ} \mathrm{C}$ with $14 \mathrm{~h}$ of light $(06: 00-20: 00 \mathrm{~h})$ per day. Food and water were available ad libitum. Hypophysectomized rats received a drinking solution of $1 \%$ dextrose (Cerelose: Sugar Supply, Des Plaines, IL) which was freshly prepared each week.

Treatments. Surgery was performed on Day 12 under clean but not aseptic conditions. Ether anaesthesia was used throughout the operations. All animals were laparotomized and the number of fetuses was recorded. After surgery each animal was injected i.m. with $20000 \mathrm{U}$ penicillin G (Eli Lilly Co., Indianapolis, IN). Hypophysectomy was done by the transauricular approach (Gay, 1967) using a stereotaxic instrument (David Kopf Instruments, Tujunga, CA). Completeness of hypophysectomy was initially determined at surgery by inspection of the extirpated pituitary. Sham-hypophysectomy involved penetration of the eardrum by the aspirating syringe without pituitary removal. Hysterectomy was performed through a midline abdominal incision. Shamhysterectomy consisted of exposing the uterus through the incision and then placing it back into the body cavity. Control rats were subjected to sham-hypophysectomy and sham-hysterectomy.

Each rat received a s.c. daily injection of $100 \mu \mathrm{g}$ oestradiol-17 3 (Sigma Chemical Co., St Louis, $\mathrm{MO}$ ) or the sesame oil vehicle in a volume of $0.25 \mathrm{ml}$ from the day of surgery until the day before autopsy.

The five treatment groups ( $\mathrm{N}=6-8$ per group) were therefore sham-operation and oil (Group 1), hysterectomy and oil (Group 2), hysterectomy and oestradiol (Group 3), hypophysectomy + hysterectomy and oil (Group 4) and hypophysectomy + hysterectomy and oestradiol (Group 5).

Tissue collection. Tissues were collected on Days 12,13,15 and 18. Rats were anaesthetized with ether and $2 \mathrm{ml}$ blood were withdrawn from the heart. Blood samples were allowed to clot for $6-14 \mathrm{~h}$ at $4^{\circ} \mathrm{C}$, and then centrifuged at $12000 \mathrm{~g}$ for $30 \mathrm{~min}$ at $4^{\circ} \mathrm{C}$ in a Beckman model $\mathrm{J}-21 \mathrm{~B}$ centrifuge (Beckman Instruments, Palo Alto, CA). Sera were frozen and stored at $-40^{\circ} \mathrm{C}$ until assayed.

Immediately after withdrawing blood, rats were killed by cervical dislocation. The ovaries were excised, cleaned of adhering connective tissue, weighed, frozen, and stored at $-40^{\circ} \mathrm{C}$ until extracted for relaxin.

To assess completeness of hypophysectomy at autopsy, adrenal glands were excised and weighed in pairs; also, the pituitary fossae were macroscopically inspected for tissue fragments.

Extraction of ovaries. Paired ovaries from each rat were homogenized in a ground-glass tissue grinder (No. 7725, Pyrex Corning Glass Works, Corning, NY) at $4^{\circ} \mathrm{C}$ with phosphate-buffered saline ( $0.14 \mathrm{M}$-sodium chloride and $0.01 \mathrm{M}$-sodium phosphate, $\mathrm{pH} 7.0 ; \mathrm{PBS})$ at a volume to weight ratio of $1 \mathrm{ml}$ PBS per $50 \mathrm{mg}$ ovarian tissue. Extracts were separated from tissue residue by centrifugation at $4^{\circ} \mathrm{C}$ for $1 \mathrm{~h}$ at $145000 \mathrm{~g}$ in a Beckman Model L5-50 ultracentrifuge. Supernatants were collected and stored at $-40^{\circ} \mathrm{C}$ until assayed.

Progesterone RIA. Progesterone concentrations in serum samples were determined by the RIA described previously (Sherwood et al., 1980). Unknown serum samples were assayed in duplicate at doses of 2.5 and $5 \mu \mathrm{l}$ and progesterone standards were done in triplicate. The interassay and mean 
intra-assay coefficients of variation for 5 assays of a serum sample on Day 19 were $15 \%$ and $14 \%$, respectively. Assay sensitivity (Feldman \& Rodbard, 1971) was 10-20 pg/tube. Logit and $\log$ transformations (Rodbard \& Lewald, 1970) of the standard curve data were done to obtain a linear dose-response curve.

Rat relaxin $R I A$. Relaxin immunoactivity concentrations in ovarian extracts and serum samples were determined by an homologous rat relaxin RIA (Sherwood \& Crnekovic, 1979). Ovarian extracts were assayed at 3 or 4 doses ranging from $2.5 \mu \mathrm{g}$ to $2.5 \mathrm{mg}$ equivalent of fresh ovarian tissue. Sera were assayed at 3 doses ranging from 2.5 to $200 \mu \mathrm{l}$. Unknown samples were analysed in triplicate or quadruplicate and rat relaxin standards were done in quadruplicate.

The interassay and mean intra-assay coefficients of variation for 15 assays of a serum sample obtained on Day 19 were $21 \%$ and $14 \%$, respectively. Assay sensitivity (Feldman \& Rodbard, 1971) was 62-125 pg/tube. Logit and log transformations (Rodbard \& Lewald, 1970) of the standard curve data were done to obtain a linear dose-response curve.

Rat prolactin RIA. Prolactin concentrations in the serum samples of rats in Groups 1, 2 and 3 on Day 18 were determined by an homologous rat prolactin RIA using materials and methods supplied by NIADDKD (National Institute of Arthritis, Diabetes, Digestive and Kidney Diseases). In brief, samples were incubated for $24 \mathrm{~h}$ at room temperature with 13000 c.p.m. rat prolactin (NIADDK-rPRL-I-5)/100 $\mu \mathrm{l}$ and $200 \mu \mathrm{l}$ diluted rabbit antiserum (NIADDK-anti-rPRL-S-8 at a final tube dilution of $1: 12500$ ). After incubation, $200 \mu \mathrm{l}$ goat anti-rabbit gamma globulin, at a dilution which enabled maximum precipitation of bound ${ }^{125} \mathrm{I}$-labelled rat prolactin, were added to each tube and the tubes were allowed to incubate for $24 \mathrm{~h}$ at room temperature. PBS ( $2.5 \mathrm{ml})$ was then added to each tube and the tubes were centrifuged at $1520 \mathrm{~g}$ for $30 \mathrm{~min}$ at $4^{\circ} \mathrm{C}$ in a Beckman Model TJ-6 centrifuge. Sera were assayed at 3 doses ranging from 10 to $60 \mu$ l. Unknown samples and rat prolactin standards (NIADDK-rPRL-RP-2) were assayed in triplicate. The intra-assay coefficient of variation for 1 assay of pooled pituitary extracts of mature female rats was $9 \%$. Assay sensitivity (Feldman \& Rodbard, 1971) was $160 \mathrm{pg} /$ tube. Logit and log transformations (Rodbard \& Lewald, 1970) of the standard curve data were done to obtain a linear dose-response curve.

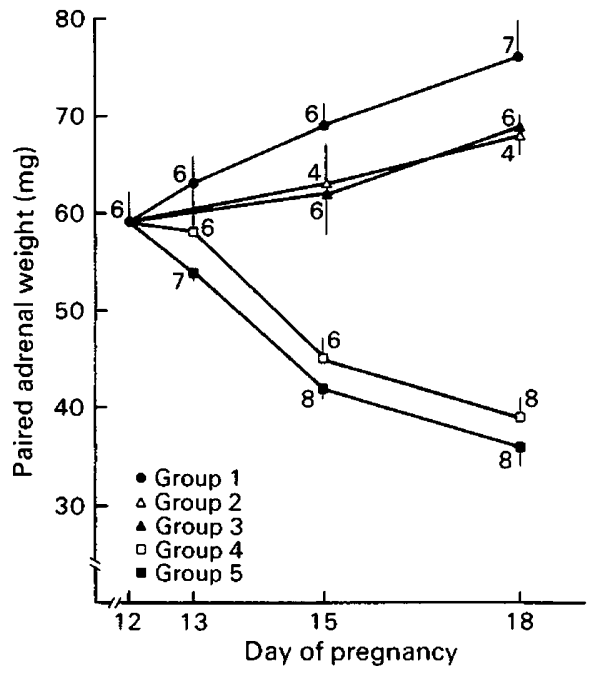

Text-fig. 1. Adrenal weights in rats in Group 1 (sham-operation and oil), Group 2 (hysterectomy and oil), Group 3 (hysterectomy and $100 \mu \mathrm{g}$ oestradiol-17ß), Group 4 (hypophysectomy + hysterectomy and oil) and Group 5 (hypophysectomy + hysterectomy and $100 \mu \mathrm{g}$ oestradiol-17 $)$. Values are mean \pm s.e.m. for the number of animals indicated. 


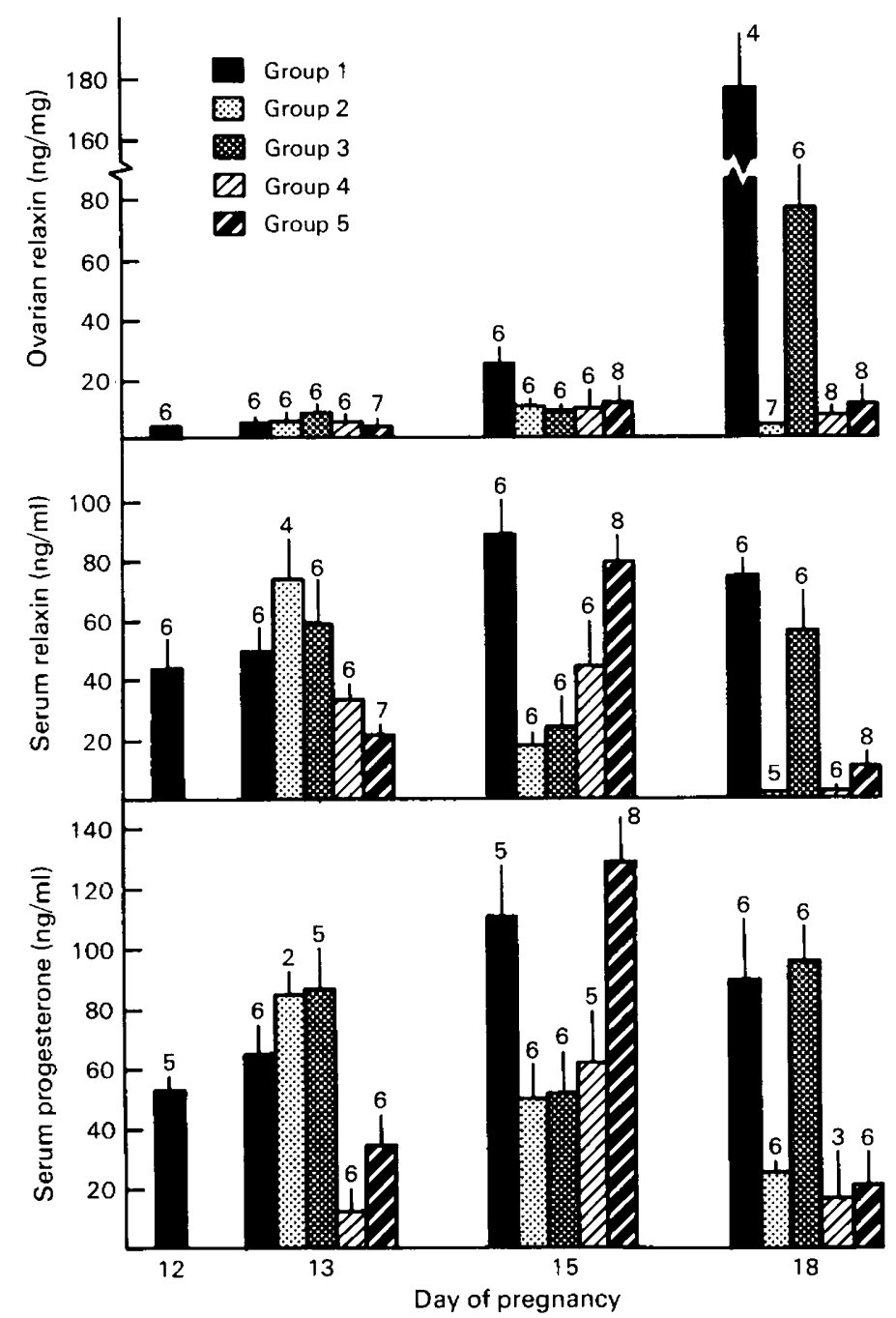

Text-fig. 2. Concentrations of ovarian relaxin, serum relaxin and serum progesterone in rats in Group 1 (sham-operation and oil), Group 2 (hysterectomy and oil), Group 3 (hysterectomy and $100 \mu \mathrm{g}$ oestradiol-17ß), Group 4 (hypophysectomy + hysterectomy and oil) and Group 5 (hypophysectomy + hysterectomy and $100 \mu$ g oestradiol-17ß). Values are mean \pm s.e.m. for the number of animals indicated.

Statistical analysis. Log transformation of data was performed to reduce the heterogeneity of variance which was revealed by Bartlett's test (Steel \& Torrie, 1960). Logarithms of data were then analysed using ANOVA and Duncan's multiple-range test at the $5 \%$ level (Steel \& Torrie, 1960).

\section{Results}

The mean \pm s.e.m. number of fetuses in all rats $(N=103)$ on Day 12 was $11 \cdot 7 \pm 0.2$ and litter size did not differ amongst treatment groups. The mean paired adrenal weights increased (Group 1, P $\leq 0.01$ ) or did not change (Groups 2 and 3) in rats with intact pituitaries from Day 12 through Day 18 , but decreased ( $\leq 0.01$ ) in hypophysectomized rats (Groups 4 and 5 ) during this period (Textfig. 1). 
The concentrations of ovarian and serum relaxin and serum progesterone in Group 1 rats increased from Day 12 through Day $18(\mathrm{P} \leq 0.01)$, but those in Group 2 and Group 4 rats were both lower than in Group 1 rats by Day 15 and declined further $(P \leq 0.05)$ on Day 18 (Text-fig. 2). Hormone concentrations in Group 3 rats were as low as those in Group 2 rats on Day 15, but increased $(\mathrm{P} \leq 0.05)$ on Day 18. The concentrations of serum relaxin and progesterone in Group 5 rats increased to levels which did not differ from those in Group 1 rats on Day 15, but were as low as those in Group 4 rats on Day 18. The ovarian relaxin values in Group 4 and Group 5 rats remained low throughout the period of study.

The mean \pm s.e.m. concentrations of serum prolactin on Day 18 in Group $2(N=4)$ and Group $3(\mathrm{~N}=5)$ rats were $18.28 \pm 4.6 \mathrm{ng} / \mathrm{ml}$ and $15.62 \pm 1.4 \mathrm{ng} / \mathrm{ml}$, respectively. These values did not differ from that in Group 1 rats $(\mathrm{N}=4)$ which was $34.96 \pm 13.7 \mathrm{ng} / \mathrm{ml}$.

\section{Discussion}

Our data support earlier findings which demonstrate that the placenta is essential for the promotion and maintenance of high concentrations of relaxin and progesterone during the second half of pregnancy in the rat (Takayama \& Greenwald, 1973; Gibori et al., 1977; Kato et al., 1979; Goldsmith et al., 1981; Golos \& Sherwood, 1982). The placental factor(s) that promotes and maintains CL function is not clearly known. It has been proposed that a placental factor which is present in increased amounts in the blood from around Day 11-14 has prolactin-like bioactivity and is luteotrophic in the rat (Glaser, Kelly \& Gibori, 1984).

Oestradiol treatment promotes luteal progesterone secretion until Day 16 in rats hypophysectomized and hysterectomized on Day 12 (Gibori et al., 1977; Ochiai \& Rothchild, 1981). The present results show that oestradiol treatment of hypophysectomized-hysterectomized rats also promotes relaxin secretion on Day 15, but not through Day 18. The ability of the CL to respond to oestradiol treatment for a limited time after hypophysectomy and hysterectomy may be due to the lingering but waning luteotrophic effect of a placental factor(s) (Gibori \& Richards, 1978). Nevertheless, the results of this study demonstrate that the $\mathrm{CL}$ in hysterectomized rats are not responsive to oestradiol treatment on Day 15. It may be that in these animals the postulated suppressive effect of the maternal pituitary on CL function after Day 12 (Ochiai, Kato, Kelly \& Rothchild, 1983; Golos \& Sherwood, 1984) overrides the waning luteotrophic effect of a placental factor(s). If this is the case, the present data could be interpreted to indicate that the suppressive effect of the maternal pituitary on serum concentrations of relaxin and progesterone on Day 15 may be acting directly on the ovary and not through the placenta.

We cannot account for the observation that the $\mathrm{CL}$ in hysterectomized rats are responsive to oestradiol treatment on Day 18, but this luteotrophic effect of oestradiol in hysterectomized but not in hypophysectomized-hysterectomized rats may be attributable to an interaction between oestradiol and maternal prolactin. It has been demonstrated (Rodway \& Garris, 1982) that daily injection of $100 \mu \mathrm{g}$ oestradiol-17 $\beta$ maintains elevated serum progesterone concentrations until Day 23 in rats that are hypophysectomized-hysterectomized on Day 12 and given 1 or 2 pituitary transplants to ensure high serum prolactin concentrations. It may be that, in the hysterectomized rats used in the present study, the maternal pituitary no longer has a suppressive effect on luteal function by Day 18, but may have exerted a luteotrophic effect by providing the prolactin needed to interact with oestradiol to promote luteal function. Our observation that prolactin is present in the serum of hysterectomized and oestradiol-treated rats (Group 3) is consistent with this hypothesis.

Our data differ from those reported by Goldsmith et al. (1982) who showed a luteotrophic effect of oestradiol in hysterectomized rats on Day 16 but not on Day 18. The major difference between the two studies is the day of pregnancy when surgery was performed. Goldsmith et al. (1982) hysterectomized their rats on Day 15 and the presence of the placentas until this time may have 
affected the responsiveness of the CL to the postulated suppressive effect of the maternal pituitary and the luteotrophic action of oestradiol.

In conclusion, our data are consistent with the concept (Golos \& Sherwood, 1982) that placental support for the promotion and maintenance of relaxin and progesterone concentrations from Day 12 through Day 18 may be mediated, at least in part, through a common mechanism(s) which involves oestradiol.

We thank Dr N. Liquido and T. G. Golos for helpful suggestions concerning statistical analyses; Dr S. Li and H. Mangian for their assistance with the prolactin RIA; the Word Processing Center of the Department of Physiology and Biophysics for help with the preparation of the manuscript, and the School of Life Sciences Artist Services for help with the figures. The work was supported by National Institute of Health Grant USPHS HD 08700.

\section{References}

Anderson, L.L., Bast, J.D. \& Melampy, R.M. (1973) Relaxin in ovarian tissue during different reproductive stages in the rat. $J$. Endocr. 59, 371372.

Anderson, M.L. \& Long, J.A. (1978) Localization of relaxin in the pregnant rat. Bioassay of tissue extracts and cell fractionation studies. Biol. Reprod. 18, 110 117.

Feldman, H. \& Rodbard, D. (1971) Mathematical theory of radioimmunoassay. In Principles of Competitive Protein-Binding Assays, pp. 158-203. Eds W. D. Odel. \& W. H. Daughaday. J. B. Lippincott Company, Philadelphia.

Gay, V.L. (1967) A stereotaxic approach to transauricular hypophysectomy in the rat. Endocrinology 81, $1177-1179$.

Gibori, G. \& Keyes, P.L. (1978) Role of intraluteal estrogen in the regulation of the rat corpus luteum during pregnancy. Endocrinology 102, 1176-1182.

Gibori, G. \& Richards, J. S. (1978) Dissociation of two distinct luteotropic effects of prolactin: regulation of luteinizing hormone-receptor content and progesterone secretion during pregnancy. Endocrinology 102, 767-774.

Gibori, G., Antczak, E. \& Rothchild, I. (1977) The role of estrogen in the regulation of luteal progesterone secretion in the rat after day 12 of pregnancy. Endocrinology 100, 1483-1495.

Glaser, L.A., Kelly, P.A. \& Gibori, G. (1984) Differential action and secretion of rat placental lactogen. Endocrinology 115, 969-976.

Goldsmith, L.T., Grob, H.S., Scherer, K.J., Surve, A., Steinetz, B.G. \& Weiss, G. (1981) Placental control of ovarian immunoreactive relaxin secretion in the pregnant rat. Endocrinology 109, 548-552.

Goldsmith, L.T., de la Cruz, J.L., Weiss, G. \& Castracane, V.D. (1982) Steroid effects on relaxin secretion in the rat. Biol. Reprod. 27, 886-890.

Golos, T.G. \& Sherwood, O.D. (1982) Control of corpus luteum function during the second half of pregnancy in the rat: a direct relationship between conceptus number and both serum and ovarian relaxin levels. Endocrinology 111, 872-878.
Golos, T.G. \& Sherwood, O.D. (1984) Evidence that the maternal pituitary suppresses the secretion of relaxin in the pregnant rat. Endocrinology 115, 1004-1010.

Golos, T.G., Weyhenmeyer, J.A. \& Sherwood, O.D. (1984) Immunocytochemical localization of relaxin in the ovaries of pregnant rats. Biol. Reprod. 30, 257-261.

Hudson, P., Haley, J., Cronk, M., Shine, J. \& Niall, H. (1981) Molecular cloning and characterization of cDNA sequences coding for rat relaxin. Nature, Lond. 291, 127-131.

Kato, H., Morishige, W.K. \& Rothchild, I. (1979) A quantitative relation between the experimentally determined number of conceptuses and corpus luteum activity in the pregnant rat. Endocrinology 105, 846-850.

Ochiai, K. \& Rothchild, I. (1981) The relation between conceptus number and the luteotropic effect of estrogen in rats after hypophysectomy and hysterectomy on day 12 of pregnancy. Endocrinology 109, 1111-1116.

Ochiai, K., Kato, H., Kelly, P.A. \& Rothchild, I. (1983) The importance of a luteolytic effect of the pituitary in understanding the placental control of the rat corpus luteum. Endocrinology 112, 1687-1695.

Rodbard, D. \& Lewald, J.E. (1970) Computer analysis of radioligand assay and radioimmunoassay data. Acta endocr., Copenh., Suppl. 147, 79-103.

Rodway, R.G. \& Garris, D.R. (1982) Potentiation by prolactin of the luteotrophic effect of oestradiol in the pregnant rat. Acta endocr., Copenh. 101, 287-292.

Sherwood, O.D. \& Crnekovic, V.E. (1979) Development of a homologous radioimmunoassay for rat relaxin. Endocrinology 104, 893-897.

Sherwood, O.D., Crnekovic, V.E., Gordon, W.L. \& Rutherford, J.E. (1980) Radioimmunoassay of relaxin throughout pregnancy and during parturition in the rat. Endocrinology 107, 691-698.

Steel, R.G.D. \& Torrie, J.H. (1960) Principles and Procedures of Statistics, pp. 67, 69. McGraw-Hill Book Company, New York.

Takayama, M. \& Greenwald, G.S. (1973) Direct luteotropic action of estrogen in the hypophysectomizedhysterectomized rat. Endocrinology 92, 1405-1413. 